DOI: 10.35218/armca.2020.1.08

\title{
A Contemporary Approach of Las Meninas
}

\section{Irina-Andreea Stoleriu*}

\begin{abstract}
The present study is meant to underline the importance of a famous work from the baroque period, Las Meninas, made by the painter Diego de Silva y Velásquez, who has become a source of inspiration for future generations of artists. Numerous modern and contemporary artists have integrally or partially "paraphrased" Velásquez's composition by intercepting the portrait of revolutionary group for the time when it was created, extremely innovative regarding its compositional qualities and its hidden meanings which underlined the role and status of the artist in the context of a conservative society. Thus, the painting becomes the living proof of the way in which the artist manages to overcome the limitations of the social status of ordinary human beings, by portraying himself as a close friend of the royal family and by opening, through this type of representation, an important chapter in the history of portraiture.
\end{abstract}

Keywords: Las Meninas; Portrait; Painting; Interepretation.

The $17^{\text {th }}$ century was characterized as "the golden age" of Spanish $\operatorname{art}^{1}$, it gave birth to a variety of creations, from dead nature and specific scenes to portraits, historical paintings, mythological or religious. The development of Spanish art was toilsome, most demands came, on the one hand, from the extremely conservative ${ }^{2}$ Church, while on the other hand, from the royal court, where foreign painters were prefered, Tizian was one of the favoured ${ }^{3}$. Among the well-known personalities of the Spanish art from that period, we also mention here Francisco Pacheco (1564-1654), José Ribera (1591-1652), Francisco Zurbaran (1598-1664), Diego de Silva y Velásquez (1599-1660), Esteban Murillo (1617-1682) and others.

Belonging to small nobility, Diego de Silva y Velásquez started his career by creating devoutness ${ }^{4}$ paintings, bodegones, portraits and historical,

\footnotetext{
* Ph.D, Lecturer, University of Arts „George Enescu” Iași, România, andreea_stoleriu@yahoo.com.

${ }^{1}$ Hermann Bauer, Andreas Prater, Barocul [Baroque], Taschen Publishing House, Köln, 2007, p. 16.

${ }^{2}$ H.W. Janson, Anthony F. Janson, History of Art: The Western Tradition, vol. II, Pearson Prentice Hall, 2004, p. 580.

${ }^{3}$ Ibidem.

${ }^{4}$ Patricia Fride-Carrassat, Maeștrii picturii [The Masters of Painting], RAO Publishing House, Bucharest, 2004, p. 132.
} 
mythological or allegorical paintings ${ }^{5}$. He learned in the workshops of Herrera the Old and then in the one of Francisco Pacheco ${ }^{6}$, being influenced by the chiaroscuro of Caravaggio ${ }^{7}$, by the compositions of El Greco and the ones of Tintoretto ${ }^{8}$, by the tardily chromatics of Tizian ${ }^{9}$ and by the "suppleness of touch, of the model, in the more vivid colour" ${ }^{\prime 10}$ of Rubens.

After the replacement of the portraitist Rodrigo de Villandrando (1588-1623) from the royal court of Filip IV ${ }^{11}$, Velásquez shortly became, because of his position of official artist, one of the most reputed painters of the $17^{\text {th }}$ century. Because he rejoiced the appreciation of the king, he was named "chief of works regarding ornaments and royal paintings for the palaces Alcazar and Buen Retiro from Madrid", , a year before his death, he received the title of knight of the Order Saint Jacob of the Sword ${ }^{13}$.

One of the most known paintings made by the artist is Las Meninas (1656) which has become one of the most loved sources of inspiration for modern and postmodern artists. They adapted and reinterpreted the message of the $17^{\text {th }}$ century work, and also the compositional ensemble through the intercession of the new visions specific to nowadays creations.

The meaning of the painting Las Meninas was often brought into discussion by art critics, one of the first interpretations of the work appeared in the $19^{\text {th }}$ century, when the art historian Carl Justi launched his theories, claiming that the image identified itself with "a part of court life accurately preserved, more than perfected by a master of objective observation ${ }^{14}$. Another art historian, Charles de Tolnay,discovered new meanings for this painting, interpreting "Las Meninas as an allegory of artistic creation" "15. In his turn, the art historian Jan Blanc synthesized these two opinions, the theory of Justi and the one of Charles de Tolnay, considering that this

\footnotetext{
${ }^{5}$ Klaus Schwager, Arta barocă [Baroque Art], in the vol. Larousse - Istoria artei [LarousseHistory of Art], coordinators Albert Châtelet and Bernard-Philippe Groslier, "Univers Enciclopedic” [,Encyclopaedic Universe”] Publishing House, Bucharest, 2006, p. 629.

${ }^{6}$ Hermann Bauer \& Andreas Prater, Barocul [Baroque], Taschen Publishing House, Köln, 2007, p. 70.

${ }^{7}$ Karin Hellwig, Painting in Italy, Spain, and France in the Seventeenth Century, în vol. Baroque: Arhitecture, Sculpture, Painting, Edited by Rolf Tomas, Ullmann \& Könemann, 2007, p. 400.

${ }^{8}$ Jan Blanc, Diego Velásquez - Prințul școlii spaniole[Diego Velásquez - the Prince of Spanish Art] in the vol. Istoria vizuală a artei [The Visual History of Art], coord. Claude Frontisi, RAO Publishing House, Bucharest, 2007, p. 265.

${ }^{9}$ Ibidem.

${ }^{10}$ Patricia Fride-Carrassat, op. cit., p. 134.

${ }^{11}$ Karin Hellwig, op. cit.,p. 400.

12 Patricia Fride-Carrassat, op. cit., p. 132.

${ }^{13}$ Jan Blanc, op. cit., p. 265.

${ }^{14}$ Jonathan Brown, Pictura spaniolă din secolul XVII [The Spanish Painting from the

$17^{\text {th }}$ Century], Meridiane Publishing House, Bucharest, 1982, p. 151.

${ }^{15}$ Ibidem.
} 
painting is more of "a chronical of palace life (...), [the work being] a true allegory of his own activity as a Court painter,"16.

Thus catalogued, the famous painting was interpreted as an expression of a specific vision of Velásquez regarding the status of the visual artist ${ }^{17}$. This idea was also underlined by the presence of the children of Rubens, discretely placed in the work, on the walls of the improvised workshop inside the Palace Alcázar, contributing to the delineation of a welldefined message which suggested "the artistic culture and the function of conservatoire" that the artist had internalized ${ }^{18}$. Consequently, the message of the painting remained open to various interpretations, being permanently renewed in time and staying open by this to "the process of a perpetual revivification" $" 19$.

Las Meninas impresses through the complexity and width of the composition, presenting a diversity of social classes inside the painting which is, in the same time, a specific scene and also a group portrait ${ }^{20}$. The action seems to be interrupted iby an unexpected event, each character being individualized in a rigorous manner, by doing a well-defined action ${ }^{21}$. The paper has numerous focus points, the workshop is divided in more plans. Thus, on the right side of the painting, the dwarves Nicolás de Pertusato, Mari-Bárbola and a dog are represented, in the centre - the infanta Margareta, framed by the two ladies of honour. On the left of the image, behind a painting which is work in progress, the artist himself is represented, while on the right, his image is in balance with the one of Marcela de Ulloa, framed by an unidentifid escort ${ }^{22}$, probably the one of the aposentador ${ }^{23}$ José $^{2}$ Nieto Velásquez, and there is also an image in the mirror of King Philip IV together with Queen Mariana, marking the father away plan, ofering depth to the pictural space.

Compositional qualities are accompanied by chromatic ones, the artist manages to establish an interesting visual balance between the characters and the described architecture. Moreover, the originality of the

\footnotetext{
${ }^{16}$ Jan Blanc, op. cit., p. 265.

${ }^{17}$ Laurie Schneider Adams, A History of Western Art, McGraw Hill, 2008, p. 362.

${ }^{18}$ Jan Blanc, op. cit., p. 265.

${ }^{19}$ Jonathan Brown, op.cit., p. 149.

${ }^{20}$ H.W. Janson \& Anthony F. Janson, op. cit. vol. II, p. 583.

${ }^{21}$ Jonathan Brown, op.cit., p. 155, "The infanta came to see the artist while working. A few moments before the raising "the curtain», she asked for drinking water which is now being offered by the kneeled maid of honour in the left. While she is offering a small cup to the princess, the king and queen enter the room and they can be seen reflected in the mirror placed on the wall in the back. One by one, but not in the same time, the gathered characters perceive the royal presence. The maid of honour from the right, who saw them first, sketches a reverence. Velásquez has also noticed the entrance and he stopped in the middle of his work; he started to lower his brush and palette".

${ }^{22}$ Jonathan Brown, op.cit., p. 149.

${ }^{23}$ José López-Rey, Velásquez, vol. II, Taschen Publishing House, 1996, p. 306.
} 
paper also consists in the fact that the presence of the artist in the same frame with he royal family has never before been met, the work becomes an act of artistic pioneerdom because of this aspect, also.

The manner of representation of the mirror reminds us of the wellknown painting of the late Middle Ages - the beginning of Renaissance, of the artist Jan van Eyck - The Arnolfini Portrait (1434), which was at the Spanish court in that period ${ }^{24}$, in this work we also meet the same motif of the reflexion of a key image regarding the deciphering of the message of the work, almost every detail of the composition has a hidden meaning ${ }^{25}$. In the painting Las Meninas, made at a temporal distance of two centuries compared to the Flemish one, the Spanish painter overtakes some elements specific to the original painting, in order to be interpreted, one of them being the mirror, placed, just like in the other painting, in the background, almost central, portraying the royal couple, this time. Just like in the work of Jan van Eyck, the mirror is used here as "a key metaphor of the pictural image ${ }^{, 26}$, leaving room for interpretations connected to the true subject of the painting and the placing of the royal couple in the scene described by Velásquez. The most powerful source of light comes from the window, just like in the case of the $15^{\text {th }}$ century work, it thus underlines the fascination of the artist for éclairage ${ }^{27}$ and also the influence of Caravaggio in the way of rendering $\mathrm{it}^{28}$. Moreover, the mirror and the half-open door offer to the viewer other interst centres, marked by light and shadow, the Spanish artist paying special attention to the materiality of objects, the refined chromatics with more intense accents of colour intending to unify the ensemble.

The master offers the proof of his full creative maturity, Las Meninasbecomes one of his referrence paintings which has inspired, in time, many generations of painters of the epochs that followed. Furthermore, the reinterpretation of this masterpiece of the history of art gave birth to a true series of works inspired by its artistic and compositional qualities, by the action of the characters, by the message of the work, byt the portrait of Margareta or by the selfportrait of the master.

The meaning of this remarkable work was reflected in later works such as Francisco Goya, Pablo Picasso, Salvador Dali, Manolo Valdés and Rafael Solves, Richard Hamilton, Cristóbal Toral, Micheline Lo, Herman Braun-Vega, Joel Peter Witkin, Fernando Botero, Celia Washington, Sophie

\footnotetext{
${ }^{24}$ Norbert Schneider, The Art of the Portrait, Taschen Publishing House, 2002, p. 150.

${ }^{25}$ Cf. Patricia Fride - Carrassat, op.cit., p. 25, ,, (...)the dog means fidelity, the last lit candle of the lustre symbolizes marriage. In the mirror, there is a more important world than the one reflected by the painting; in it, we can see three silhouettes, of the married couple and of an observer, the spectator or the painter, this creator introduces us in another universe, dumb, concentrated, eternal. «Johannes de Eyck fuit hic» (Jan van Eyck was here)"

${ }^{26}$ Victor Ieronim Stoichiță, Instaurarea tabloului, Editura Meridiane, București, 1999, p. 217.

${ }^{27}$ H.W. Janson și Anthony F. Janson, op. cit. vol. II, p. 583.

${ }^{28}$ Ibidem, p. 584.
} 
Matisse, Eve Sussman, Lluis Barba sau Alexander Stanuga, who have found in the work of Veláquez an important model. This modernizing of the painting Las Meninas was concretized, in the work of each modern or contemporary artist, in a distinct manner. Thus, Picasso created, in his specific style, numerous sketches and paintings, Salvador Dali and Fernando Botero found their inspiration in the selfportrait of Velásquez, Joel Peter Witkin interpreted the compositional ensemble through the means of the photography, while Eve Sussman directed a movie which underlined the action that took place in the royal palace.

One of the mentioned artists, the Spanish painter Francisco Goya y Lucientes (1746-1828) dedicated himself to portraiture, having three masters: Rembrandt, Velásquez and nature ${ }^{29}$. Inspired by Velásquez's Las Meninas, Goya created sketches and engraving with the same name and a painting -The Family of Carol IV-,in which one can feel the stylistic influence of the original painting, synthesizing "psychological and physical truths" ${ }^{30}$ through the realistic manner lacking any idealization of the representation of characters.

These works have marked a transition period for the reinterpretative evolution of the work Las Meninas, making the connection with modern times and with the most famous series of this kind, also made by a Spanish artist, Pablo Picasso(1881-1973).In the creation of Picasso, figurative art has played an essential role by "expanding the possibilities and the parameters of portraiture ${ }^{31}$. The Spanish artist invented and reinvented abstract, surrealist, classic and expresionist painting, starting from the realistic vision that he gradually left behind in order to let his imagination transform the physiognomy of the model, distorting it and permanently challenging the viewer, given the novelty of his style ${ }^{32}$. By these features, Picasso marked the moment of a deep artistic change by deepening the analysis of the ambiguity of representation ${ }^{33}$. Thus, the work of Picasso has also enjoyed a scientific approach, the one of Carl Gustav Jung, he analysed the psychology which was the basis of the Spanish artist, reaching the conclusion that "non-realistic art essentially receives its content from the «inner side» (...)[from] the unconscious soul, ${ }^{34}$. Referring to this aspect, his work has known a major stylistic transformation, causing problems regarding the differences between

\footnotetext{
${ }^{29}$ Patricia Fride - Carrassat, op.cit., p. 176.

${ }^{30}$ Ibidem., p. 177.

${ }^{31}$ William Rubin, Reflections on Picasso and Portraiture, in the vol. Picasso and Portraiture: Representation and Transformation, Edited by William Rubin, Published by The Museum of Modern Art, New York, 1996, p. 13.

${ }^{32}$ Ibidem, p. 14.

${ }^{33}$ Edina Bernard, Arta Modernă 1905-1945 [Modern Art 1905-1945], "Meridiane" Publishing House, 2000, p. 41.

${ }^{34}$ Carl Gustav Jung, Picasso, in the vol.Opere complete, vol. 15: Despre fenomenul spiritului în artă și știință [About the Phenomenon of the Spirit in Art and Science], 'Trei" Publishing House, 2007, pp. 142-143.
} 
the portraits made after real people and the ones which only skematically describe tha face and human figure.

Having its roots in the art of the past, the cubist painter has created new ways of perciving reality, sometimes finding his inspiration in more paintings in order to bring a single project to an end. Thus, in the late work of Picasso, after the year 1946, one can see the presence of a series of reinterpretations of some famous works, such as Venus and Cupidby Lucas Cranach, Las Meninas andEl Boboby Diego Velásquez, The Man with the Golden Helmetof Rembrandt van Rijn, Women on the Shore of the Seigneby Gustave Courbet or Breakfast on the Grass and Lola of Valencia by Edouard Monet. Just like the art historian Ingo F. Walther claims, the re-interpretation of the works of the past in a modern manner was "an essential part of the creative process of Picasso",35. This paraphrasing offered a new dimension to the creation of the artist, in his youth, making him shape his own formal language ${ }^{36}$, and in his late work, as a method of reviving his style.

Velásquez's Las Meninas have also constituted the source of inspiration of a great number of creations signed by Picasso (according to some opinions, forty-four ${ }^{37}$, while others claim fifty-eight ${ }^{38}$ ), the inner motivation of the artist when choosing this work consists in the fact that he treated one of his favourite topics, the one of the connections between painter and model ${ }^{39}$. On Las Meninas, the modern artist intervened, both at a compositional and a stylistic level, and also a chromatic one, the format of the original work being modified from vertical to horizontal. Furthermore, the realistic style of Velásquez was transformed in one close to Cubism and naïve painting, clid-made, and from the rich original chromatics, he chose a monochrome version.

After numerous studies, Picasso has managed to perfect the compositional structure, interpreting the hierarchical placing of the characters that initially seemed to constitute a radiography of life at the Spanish court of the $17^{\text {th }}$ century. But, differences do not stop here, in the painting of the $20^{\text {th }}$ century, the selfportrait of Velásquez was replaced by the one of Picasso, the modern artist thus re-upgraded the image. Unlike the original painting, the self-portrait of the cubist artist, placed in the lfet side of the painting, was represented at a much bigger scale (the entire face), occupying an important surface of the composition. Though, in this case, the work manner of the artist was typically cubist, the rest of the image has more of an infantile style, reminding us of the works of children and of Guernica, the master

\footnotetext{
${ }^{35}$ Ingo F. Walther, Picasso, Taschen Publishing House, Köln, 2003, p. 82.

${ }^{36}$ Ibidem.

${ }^{37}$ Ibidem.

${ }^{38}$ Carsten-Peter Warncke, Pablo Picasso 1881-1973, vol. II, Edited by Ingo F. Wsalther, Editura Taschen, 2007, p. 603.

${ }^{39}$ Ibidem.
} 
intentionally left the sensation of a rough sketch. Though it seems unfinished, the painting of Picasso was not deprived of the realization of some details, similar to the characters that appear in the work of the baroque artist. Unlike the work of Velásquez, the representation of the dwarf and of the dog in the right part of the image did not receive special attention. The same work manner also defined the way in which objects were made, the half-open door, the paintings on the wall, the windows on the right side of the work, the canvas and the easel used by the artist.

Moreover, except for this painting, Picasso has many other studies made after the infanta and one of the maids of honour, but all these attempts had an abrupt coming to an end, being finally catalogued as failures ${ }^{40}$.

Another referrence artist was Salvador Dali, he is also the one who elaborated the so-called method"critic paranoia" 41 . The creation of this extravagant artist who shortly became a true "star" of the artistic field ${ }^{42}$, was based on the theories of the psychoanalysis of Freud who tried to bring "the subconscious to the level of conscious and thus, to heal the soul sick of one's own discharge ${ }^{, 43}$.

Regarding the reinterpretation of the work Las Meninas, Dali has taken over just some details from the work that served him as a source of inspiration, focusing his attention on the selfportrait of Velásquez. Thus "in a sequence of photographic montage, the face of Dali (...) [was] stept by step superposed to the one of Velásquez, in order to show that he(...) [is] the truemodern "reincarnation» of the classical master" 44 , the result being a hybrid image whose artistic realities gave the name to a new work of art: From Velásquez to Dali. Between the two faces, there have been obvious similarities that Dali knew how to speculate, proving his artistic genius.

Common aspects were synthesized in the central image, it presented both the elements which are characteristic to the portrait of Velásquez and the ones specific to Dali. The work From Velásquez to Dali was part of a larger series of photomontage, in which the surrealist painter showed himself as some famous characters, this workmethod reminding us of another famous

\footnotetext{
${ }^{40}$ Carsten-Peter Warncke, op. cit., vol. II, p. 611.

${ }^{41} \mathrm{Cf}$. Albert Châtelet, De la întoarcerea la ordine la cel de-al doilea război mondial [From Return to Order to the Second World War], in the vol. Larousse - Istoria artei [Larousse The History of Art], coordinators Albert Châtelet and Bernard-Philippe Groslier, "Univers Enciclopedic" Publishing House, Bucharest, 2006, p. 793, critic paranoia represents a "spontaneous method of irrational knowledge, based on the interpretative-critic association of delirious phenomena".

${ }^{42}$ Gilles Néret, Dali, Taschen Publishing House, Köln, 2003, p. 8.

43x x x , Istoria artei: Pictură, Sculptură, Arhitectură [History of Art: Painting, Sculpture,

Architecture], RAO Publishing House, Bucharest, 2000, p. 276.

${ }^{44}$ Gilles Néret, op. cit., p. 58.
} 
reinterpretation, the one of Picasso, both modern artists substituted the face of Velásquez, and also overtook a part of his visual and artistic identity.

Identity coincidences connected to the Spanish origin of these three creative personalities have helped this practice to become a success, their works constituting a landmark in the history of art and innovative styles that made them famous in the artistic field.

$$
\text { **** }
$$

One of the representatives of British Pop-Art, Richard Hamilton (n. 1922), has made a series of interpretations after Picasso's Las Meninas, the purpose was to pay homage to the creation of this great modern master. Exhibited in 2010 in Prado Museum, his reinterpretations appealed to a various range of technical means which served as a way of bringing up-todate Las Meninas of Velásquez.

Regarding the tribute paid to the creation of Picasso, in an interview from $2010^{45}$, Richard Hamilton claimed that this reinterpretation combines both the compositional elements from the creation of Velásquez to the ones specific to modern artist, shaping the hint to the blending of the past with the present $^{46}$. From a compositional point of view, Hamilton has respected the compositions of his predecessors, bringing specific updates to the work. In this respect, the selfportrait of Velásquez was replaced by the image of Picasso, while in the way of representing the other characters, he reminds us of the work of the cubist master. Furthermore, the portraits of the king and queen, reflected in the mirror in the background, were replaced by the selfportrait of the postmodern artists and his wife, while the copies after Rubens on the walls of the workshop from the painting of Velásquez - with some of the works of Picasso.Regarding the chromatic aspect, Hamilton appealed to the self-colour specific to Las Meninas of Picasso, starting from the white of the paper (at the bottom of the work) and reaching the mat and sullen aspect from the upper part of the image. Between these two extremes, he used a various series of greys, suggesting in this way and through stylistic changes, the interet centres of the work.

This creation has enriched the portfolio of graphic works Hommage à Picasso ${ }^{47}$ presented in the exhibition organized on the occasion of the celebration of 90 years from the birth of the great cubist artist, offering

\footnotetext{
45 http://www.museodelprado.es/en/exhibitions/exhibitions/at-the-museum/richard-hamilton-picassosmeninas/videol, last seen on 23.03.2020.

${ }^{46}$ http://www.museodelprado.es/en/exhibitions/exhibitions/at-the-museum/richard-hamilton-picassosmeninas/emlas-meninas-de-picassoem/emlas-meninas-de-picassoem-de-richard-hamilton/, last seen on 23.03.2020.

${ }^{47}$ http://www.museodelprado.es/en/exhibitions/exhibitions/at-the-museum/richard-hamiltonpicassos-meninas/emlas-meninas-de-picassoem/hommage-a-picasso/, last seen on 23.03.2020.
} 
continuity to the reinterpretations of the baroque work, appealing not to the creation of Velásquez, but to the modern one of the Spanish cubist ${ }^{48}$.

Beside Goya, Picasso, Dali and Hamilton, Cristóbal Toral and Sophie Matisse are other two artists who have reinterpreted the painting Las Meninas, conferring it new meanings. In D'après Las Meninas, Cristóbal Toral replaced the characters from the foreground of the painting of Velásquez with numerous suitcases and boxes similar to the ones of poor emigrants, transforming them into a true metaphor of global migration ${ }^{49}$.

Recreating the space which is characteristic to Las Meninas, Toral left the viewer the liberty of interpreting this work, by placing just a few hints connected to the atmosphere of the workshop of Velásquez from Alcazar Palace.

Unlike the work of Toral, Sophie Matisse prefered a distinct approach, giving up on rendering characters and keeping only the ambient which reminded of life at the Spanish court of the $17^{\text {th }}$ century. In this respect, the viewer can almost automatically remember the loading of the original composition, by contrast with it, specific affective sides become active, even nostalgic, motivated by the awareness of time passing. The impact of placing Velásquez's work near its $21^{\text {st }}$ century reinterpretation is extraordinary, at the level of perception of the viewer, the ensemble of these two images creates the sensation of a "scene" common to the $17^{\text {th }}$ and $21^{\text {st }}$ centuries, in which people are bare actants at that moment.

Unlike the animated work of the baroque artist, the work of Sophie Matisse offers the sensation of enterring a museum room in which the vital element is missing, the only aspect that is still trying to transmit something from the initial atmosphere is represented by the paintings from the background wall and the common inner frame of the two scenes. The absence of the characters from the contemporary painting and also the half-open door represent, in fact, a symbolic presence in the conscience of the viewer, the image of Las Meninas still persists, even after so many centuries, their absence emphasizes the impact and notoriousness of the work of Velásquez.

$* * *$

Another original approach of Las Meninas can also be encountered in the creation of the American photographer Joel Peter Witkin (n. 1931),

\footnotetext{
${ }^{48}$ Harold Rosenberg, Art on the edge: creators and situation, University Press of Chicago Press, 1983, p. 68.

${ }^{49}$ Silvia Spitta, Misplaced objects: Migrating Collections and Recollections in Europe and the Americas, University of Texas Press, 2009, p. 201.
} 
known in the history of art for his grotesque and macabre works ${ }^{50}$. Mainly, the influences from his works relate to two traditions, a religious one and a modern one ${ }^{51}$, the contemporary artist finds his source of inspiration in the works of great masters, as it is the case of the famous work which is the subject of the present part of our study.

The psychological explanation of the recourse to reinterpretation is offered in the present case by the artist himself, who, when he was six years old, was involved in a serious car accident that marked him forever, this event has been reflected in his later artistic creation ${ }^{52}$. A good example in this respect regarding the influences felt by the artist because of this difficult moment was the creation of the sketch for the photographyLas Meninas called $M e$, Crippled, that the theoretician psychoanalyst Parveen Adams had interpreted as a substitution of the victims that the artist had seen in the accident from his childhood ${ }^{53}$.

Regarding the photography Las Meninas, Witkin replaced the image of the infanta with the one of an infirm little girl, placed in the centre of the composition, sitting on a crinoline with roller skates and holding in leash the dog that was in the fore-front of the work. Just like his predecessors, the artist made his own portrait working on the left side of the image, taking Velásquez's place from the $17^{\text {th }}$ century painting. The amalgam of characters, objects and styles found in Las Meninas of Joel Peter Witkin transforms the painting of Velásquez in an image which is difficult to decipher visually and conceptually, this imagistic renewal simultaneously reminds us of the composition of the Spanish artist, of Picasso's style, of religious art and the childhood obsessions of the author.

In the field of reinterpretation, Celia Washington has also become known, being considered one of the most talented contemporary artists, wellknown for her works, preferring oil painting, drawing and stencilprocess. In her work, the artist was influenced by the representative masters of the history of art, ever since she was a student inspired by the works of Chagall and Munch, then the ones of Goya, Picasso, Dubuffet, Beckmann, Basquiat or Barceló ${ }^{54}$.

In the work Journey to the End of the Night/Viaje al fin de la noche, the artist has taken over and interpreted a character of Velásquez's Las

\footnotetext{
${ }^{50}$ Mark Stevens, Beauty and the Beast, in New York Magazine, vol. 28, No. 45, 1995, p. 91.

${ }^{51}$ Ibidem.

${ }^{52}$ Parveen Adams, ,, Se faire être une photographie”: The Work of Joel-Peter Witkin, in the vol. Art: sublimation or sympton, Editor Parveen Adams, Karnac Books, p. 166.

${ }^{53}$ Ibidem.

${ }^{54}$ Hearher Waddell, London Art and Artists Guide, Published by London Art and Artist's Guide, London, 2006, pp. 28-29.
} 
Meninas - infanta Margareta -, transposing in etching her double portrait. Celia Washington thus manages to harmoniously combine human faces with writing, visual elements are put in light by the ornamental blue background.

The centre of the composition is occupied by the portrait of two feminine characters, the text being placed in the left superior corner and inferior right of the image, its placing thus emphasizing the decendent diagonal of the work. Structured in this way, the work of Celia Washington concretizes a new formula of reinterpretation of Las Meninas, establishing a rapport specific between the features of baroque work and postmodern elements that she manages in an innovative manner, characteristic to contemporary art.

The reinterpetative and descriptive process of Las Meninasof Velásquez was also continued by the American artist Eve Sussman, she transformed the painting of the $17^{\text {th }}$ century in a contemporary movie called 89 Seconds at Alcázar (2004). In an interview of the artist, she justified the idea of the movie by the powerful emotion she had when she saw with her own eyes the famous baroque work at Prado Museum in Madrid, evoking the almost photographic manner in which rendered space, characters and the action herself.

Underlining the precedential phases of painting, the artist underlined the moment in which the characters get prepared to model for the artist, whispering and transmitting through body language the relationship between them and the viewer ${ }^{55}$. Regarding this new way of reinterpreting the painting Las Meninas, the film critic Geoff Andrew has mentioned that there are are specific connections to the works from the past, intentionally made by contemporary artists or not, underlined by the relationship between the realism of Velásquez's painting, the way of treating characters, the passing of time, the presence or the absence of the artist from the work and last, but not least, by the way in which the painter and some of the characters directly look at the viewer ${ }^{56}$.

For this project, the artist has collaborated with a team of specialists formed of the architect Robert Whalley, the choreographer Claudia de Serpa Soares, the clothes designer Karen Young and the eleven actors who played the role of the characters of Velásquez ${ }^{57}$. Through this movie, this reinterpretation has artistically exemplified the enactment of the action from Velásquez's painting, Sussman thus contributing to the imagistic evolution of Las Meninas up to contemporary times.

\footnotetext{
${ }^{55}$ Richard Lewis \& Susan I. Lewis, The Power of Art, Wadsworth Publishing, 2009, p. 470.

${ }^{56}$ John Gill, Andalusia: a Cultural History, Oxford University Press, New York, 2009, p.133.

${ }^{57} \mathrm{http} / / / \mathrm{www}$.ricegallery.org/new/exhibition/89secondsatalcazar.html, last seen on 12.03.2020.
} 
In the end, we conclude on the fact that Las Meninas, the famous work of the Spanish painter Velásquez has become a reference point for the evolution of the European art from the $17^{\text {th }}$ century, being appreciated for the rigorous composition, the accuracy of the detailspresented in a naturalistic manner and the diversity of the social typologies joined in a single image.

The permanent update through reinterpretations of this masterpiece of baroque art creates a bird's eye view on the manner of evolution of art, permanently rapporting itself to the past. This type of images continues to offer clues regarding the concept of work of art, through eloquent examples which target at stylistic and technical renewal, specific to each epoch.

\section{Bibliography:}

Bauer, Hermann and Prater, Andreas, Barocul [Baroque], Taschen Publishing House, Köln, 2007.

Bernard, Edina, Arta Modernă 1905-1945 [Modern Art 1905-1945], "Meridiane" Publishing House, 2000.

Brown, Jonathan, Pictura spaniolă din secolul XVII [The Spanish Painting from the $17^{\text {th }}$ Century], Meridiane Publishing House, Bucharest, 1982.

Fride-Carrassat, Patricia, Maeștrii picturii [The Masters of Painting], RAO Publishing House, Bucharest, 2004.

Gill, John, Andalusia: a Cultural History, Oxford University Press, New York, 2009.

Gustav Jung, Carl, Picasso, in the vol.Opere complete, vol. 15: Despre fenomenul spiritului în artă și știință [About the Phenomenon of the Spirit in Art and Science], "Trei" Publishing House, 2007.

Hellwig, Karin, Painting in Italy, Spain, and France in the Seventeenth Century, în vol. Baroque: Arhitecture, Sculpture, Painting, Edited by Rolf Tomas, Ullmann \& Könemann, 2007.

Ieronim Stoichiță, Victor, Instaurarea tabloului, Editura Meridiane, București, 1999.

Janson, H.W. and Janson, Anthony F., History of Art: The Western Tradition, vol. II, Pearson Prentice Hall, 2004.

Lewis, Richard \& Lewis, Susan I., The Power of Art, Wadsworth Publishing, 2009. López-Rey, José, Velásquez, vol. II, Taschen Publishing House, 1996.

Néret, Gilles, Dali, Taschen Publishing House, Köln, 2003.

Rosenberg, Harold, Art on the edge: creators and situation, University Press of Chicago Press, 1983.

Rubin, William, Reflections on Picasso and Portraiture, in the vol. Picasso and Portraiture: Representation and Transformation, Edited by William Rubin, Published by The Museum of Modern Art, New York, 1996.

Schneider Adams, Laurie, A History of Western Art, McGraw Hill, 2008.

Schneider, Norbert, The Art of the Portrait, Taschen Publishing House, 2002.

Spitta, Silvia, Misplaced objects: Migrating Collections and Recollections in Europe and the Americas, University of Texas Press, 2009.

Stevens, Mark, Beauty and the Beast, in New York Magazine, vol. 28, No. 45, 1995. 
Walther, Ingo F., Picasso, Taschen Publishing House, Köln, 2003.

Warncke, Carsten-Peter, Pablo Picasso 1881-1973, vol. II, Edited by Ingo F. Wsalther, Editura Taschen, 2007.

*** Istoria vizuală a artei [The Visual History of Art], coord. Claude Frontisi, RAO Publishing House, Bucharest, 2007.

*** Larousse - Istoria artei [Larousse - History of Art], coordinators Albert Châtelet and Bernard-Philippe Groslier, "Univers Enciclopedic” [,Encyclopaedic Universe"] Publishing House, Bucharest, 2006.

***, Art: sublimation or sympton, Editor Parveen Adams, Karnac Books, p. 166.

Hearher Waddell, London Art and Artists Guide, Published by London Art and Artist's Guide, London, 2006.

***, Istoria artei: Pictură, Sculptură, Arhitectură [History of Art: Painting, Sculpture, Architecture], RAO Publishing House, Bucharest, 2000.

http://www.museodelprado.es/en/exhibitions/exhibitions/at-the-museum/richard-hamiltonpicassos-meninas/videol, last seen on 23.03.2020.

http://www.museodelprado.es/en/exhibitions/exhibitions/at-the-museum/richard-hamilton-picassosmeninas/emlas-meninas-de-picassoem/emlas-meninas-de-picassoem-de-richard-hamilton/, last seen on 23.03.2020.

http://www.museodelprado.es/en/exhibitions/exhibitions/at-the-museum/richard-

hamilton-picassos-meninas/emlas-meninas-de-picassoem/hommage-a-picasso/, last seen on 23.03.2020.

http://www.ricegallery.org/new/exhibition/89secondsatalcazar.html, last seen on 12.03.2020. 